\title{
Density, numbers and probable origin of Northern Hawk Owls Surnia ulula in southern Norway during the 2016 irruption
}

\author{
Svein Dale
}

Faculty of Environmental Sciences and Natural Resource Management, Norwegian University of Life Sciences, P.O.Box 5003, NO-1432 Ås, Norway; e-mail: svein.dale@nmbu.no

\begin{abstract}
One of the largest known irruptions of Northern Hawk Owls Surnia ulula in southern Norway started in mid August 2016. During September-October I conducted $246 \mathrm{~km}$ surveys in boreal forests in Oslo and Akershus counties, southeastern Norway. A total of 16 owls was detected. Depending on assumptions regarding detectability, a density of 0.106-0.204 owls $/ \mathrm{km}^{2}$ was estimated, corresponding to 371-714 individuals in boreal forests of the two counties in total. Southeastern Norway has about $55600 \mathrm{~km}^{2}$ boreal forest which implies a total of 5894-11342 owls in this habitat. According to the bird reporting websites www.artsobservasjoner.no and www.nofoa.no there were 1366 reports of Hawk Owls from all counties in southern Norway during September-October, representing 661 different sites. In Oslo and Akershus counties, estimates suggested that $<10 \%$ of all Hawk Owls were detected. A $5-10 \%$ detection rate suggests that there were 6610-13220 owls in southern Norway. However, in many counties Hawk Owl reporting rates measured as proportion of all bird reports that concerned Hawk Owl, were much higher than in Oslo and Akershus, which could imply higher density. By adjusting density (using the values $0.10-0.204 \mathrm{owls} / \mathrm{km}^{2}$ from boreal forest in Oslo and Akershus) for county-specific owl reporting rates, the number of Hawk Owls present only in boreal forest in southeastern Norway was estimated at 14466-27872 individuals. This number excludes additional owls in agricultural areas and owls in other parts of southern Norway. Overall, a total number of about 10000-20000 individuals is considered most likely. I review available evidence of the origin of these owls using number of reports and spatial distribution of Hawk Owls in northern Norway, Sweden, Finland, Estonia and Russia during 2015 and 2016. I conclude that the Hawk Owls came from northern Fennoscandia where large numbers bred in 2015, and not from more eastern areas such as Russia.
\end{abstract}

Key words: autumn density, rodent cycles; Surnia ulula; origin of irruption

\section{INTRODUCTION}

In northern boreal regions, numbers of many raptors fluctuate in synchrony with regular cycles of their rodent prey (Cheveau et al. 2004, Sundell et al. 2004). During rodent peaks, breeding success of the raptors is high, but when rodent numbers subsequently collapse, large numbers of raptors may be forced to migrate in order to find new areas with sufficient food supplies (e.g. Sonerud et al. 1988). Thus, periodical irruptions of in particular owls specialized on rodents are wellknown (Newton 2006). In southern Scandinavia, Northern Hawk Owls (Surnia ulula), hereafter Hawk Owls, are scarce breeders (Sonerud 1994), but have occurred in large numbers in autumn and winter in certain years. Irruptions have been recorded in 191213 (Hagen 1956), in 1950-51 (Holgersen 1951, Edberg 1955, Hagen 1956), in 1983-84 (Jacobsen 1984, Svensson et al. 1999, Douhan 2014, Larsen 2016), and in 2012-13 (Douhan 2014). The number of individuals involved in Hawk Owl irruptions has rarely been estimated, but 2000-4000 individuals were thought to be present in Värmland in Sweden during the 1983-84 irruption (Svensson et al. 1999).
In 2016, a new major irruption, starting in August, took place with large numbers of Hawk Owls reaching most parts of southern Norway (e.g. Larsen 2016) as well as southern Sweden (e.g. Natursidan.se 2016). A large number of sightings have been reported on the website of the Norwegian Biodiversity Information Centre (www. artsobservasjoner.no). To assess density of Hawk Owls in boreal forest, which is their main habitat, I conducted surveys along roads in five parts of Oslo and Akershus counties during September-October 2016. I use the results from these surveys to estimate the total number of Hawk Owl individuals that were present in boreal forests in the two counties, and then to extrapolate to boreal forests in southeastern Norway. To assess numbers in the whole of southern Norway during this time period of the irruption, I also extracted information on the number of Hawk Owl reports and the number of different sites with Hawk Owls from www. artsobservasjoner.no. Finally, I reviewed available evidence of the most likely origin of this Hawk Owl irruption. Previously, there has been disagreement as to whether the 1950-51 irruption had an eastern origin such as Russia (Holgersen 1951, Edberg 1955, Mikkola 1983) or originated from within Fennoscandia (Hagen 
1956).

\section{METHODS}

\section{Field study area and study period}

I conducted surveys in five parts of Oslo and Akershus counties $\left(59.71-60.46^{\circ} \mathrm{N}, 10.59-11.91^{\circ} \mathrm{E}\right)$ during five days in the period 25 September -29 October 2016 (see Appendix 1). Survey sites were in boreal forest at altitudes of 170-470 m above sea level. Boreal forests in the study area were dominated by Norway Spruce (Picea abies) and Scots Pine (Pinus sylvestris) and heavily influenced by modern forestry, with a large proportion of clear-cuts. A total of $246 \mathrm{~km}$ was surveyed (40-76 km per day). Surveys were limited to September-October because the purpose of the study was to obtain an estimate of the total number of owls that had reached southern Norway during the peak of the irruption (cf. Jacobsen 1984), before mortality may have reduced numbers. There were numerous reports of injured or killed owls along roads, other accidents, or weakened birds (see Appendix 2). In addition, a large snowfall on 5 November in parts of southeastern Norway (including parts of Oslo and Akershus) may have caused a redistribution of individuals in response to more difficult hunting conditions on clear-cuts (cf. Sonerud 1986, Nybo \& Sonerud 1990). Some individuals may then have moved from boreal forest to agricultural areas in the lowlands with less snow cover, or they may have turned to hunting more within forest and thereby making detectability lower (Sonerud 1986, Nybo \& Sonerud 1990).

\section{Survey methods}

Surveys were carried out by driving by car $(143 \mathrm{~km})$ or bicycling $(103 \mathrm{~km})$ mainly on forestry roads (narrow gravel roads with little traffic; larger roads with tarmac and some traffic were followed mainly on 25 October). I searched for Hawk Owls by stopping and scanning at every clear-cut along the roads surveyed. This method was chosen because hawk owls hunt from elevated perches giving a wide view such as from remaining trees on forest clear-cuts (Sonerud 1992, 1997) when the ground is not snow-covered (Sonerud 1986, Nybo \& Sonerud 1990), and because clear-cuts were the most common open habitat in the study area. Scans were only made with hand-held binoculars (10 x magnification), and telescope was only used to confirm species identity of distant individuals. There was no difference in detection rate in relation to locomotion mode [car: 0.070 individuals $/ \mathrm{km}$ (10 individuals, $142.6 \mathrm{~km})$, bicycle: 0.058 individuals $/ \mathrm{km}$ (6 individuals, 103.1 $\mathrm{km})$; expected values if encounter rates were equal: car:
9.3 individuals, bicycle: 6.7 individuals; $\chi^{2}=0.13$, df $=1, \mathrm{p}=0.72]$. Surveys were carried out from sunrise to late afternoon or sunset. Total survey duration was 37 hours (6.8-8.2 hours/day). Analyses indicated that number of owls per km surveyed stabilized after a few days of survey (see Appendix 3), thus total survey effort seemed to be sufficient to obtain a reliable estimate of density.

\section{Estimation of density within the study area}

Estimated density may depend on the width of the survey band along the roads followed. Distances to owls detected were measured on aerial photographs (www.norgeibilder.no), and were 20-870 m (median $100 \mathrm{~m})$. Distances from owl to road were $20-870 \mathrm{~m}$ (median $80 \mathrm{~m}$; see Appendix 4). Of 16 owls detected, 13 were within $250 \mathrm{~m}$ from the road whereas the remaining three individuals were $630-870 \mathrm{~m}$ from the road (see Appendix 4). The latter three individuals were discovered across lakes (2) and across a valley (1). Thus, it is likely that a fairly large proportion of owls within $250 \mathrm{~m}$ from the road were detected, and the number observed within $250 \mathrm{~m}$ was used as a minimum density estimate.

Most clear-cuts encountered along the survey roads allowed open views of up to a few hundred meters. However, clear-cuts that were not directly visible from the road (due to dense forest), but still within a few hundred metres from the road were not checked. To assess the proportion of clear-cuts within $250 \mathrm{~m}$ from the road that were checked, I used aerial photographs from www.norgeibilder.no for the areas surveyed during the four days with owls encountered. This analysis suggested that approximately $75 \%$ of clearcuts within $250 \mathrm{~m}$ from roads had been checked. Based on the proportion of clear-cuts checked, a more realistic density estimate was thus obtained by multiplying the number of owls detected within $250 \mathrm{~m}$ by a factor of 1.33 .

Finally, the number of owls observed declined with distance from the road up to a distance of $250 \mathrm{~m}$ (see Appendix 4). Assuming that real owl density was unrelated to distance from road, a maximum density estimate was based on the density within $50 \mathrm{~m}$ from the road. Five owls were detected within a distance of $50 \mathrm{~m}$ from the road (see Appendix 4) which would suggest there were in reality 25 owls within a distance of $250 \mathrm{~m}$ from the road. Thus, the maximum density estimate was obtained by multiplying the number of owls detected within $250 \mathrm{~m}$ (13 individuals) by a factor of 1.92 (25/13; corresponding to a $52 \%$ detection rate within $250 \mathrm{~m}$ from roads).

Hawk Owls were detected throughout the day with no peak in the morning as for many other bird species (see Appendix 5). Thus, results were not corrected 
for time of day. Distance to the closest other Hawk Owl for each Hawk Owl detected during surveys was $1.3-14.3 \mathrm{~km}$ (median $4.4 \mathrm{~km}$ ), but there was only one case where owls were closer than $2.7 \mathrm{~km}$ to each other. Bekken et al. (1987) found that the autumn home range of one Hawk Owl was $2.7 \mathrm{~km}^{2}$. Thus, most of the owls recorded were likely to be different individuals. Furthermore, even though two separate observations may involve the same owl that had moved between the two sites, this should not bias density estimates, as it is equally likely that I missed the owl in both sites during the period I made my observations.

\section{Boreal forest area}

To calculate total number of individuals present in boreal forest, I used information of total forest area from Larsson (2013). These figures are higher than the area of productive forest, but forest classified as unproductive is suitable habitat for Hawk Owls and was therefore included in this study. The total forested area does not only include boreal forest, but also boreonemoral and nemoral forest. However, both Oslo and Akershus, and other counties in southeastern Norway (Østfold, Hedmark, Oppland, Buskerud, Vestfold, Telemark and Aust-Agder), have only about 1\% nemoral forest (Sunding \& Hjermann 2009). Boreonemoral forest also constitutes a small proportion of the forest in this region, but this type of forest was regarded as potentially suitable for Hawk Owls and was included in the forest area considered in this study.

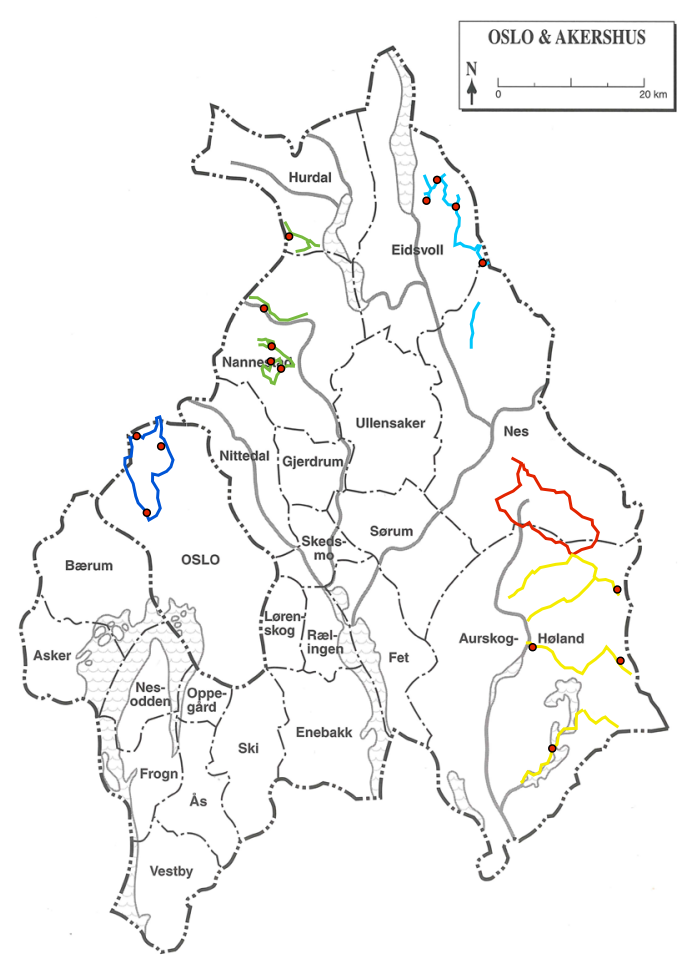

Number of Hawk Owls reported in southern Norway

I accessed the websites of the National Biodiversity Information Centre (www.artsobservasjoner.no) and BirdLife Norway, Oslo and Akershus branch (www. nofoa.no) on 30 November 2016 and extracted all Hawk Owl reports. To remove multiple reportings of the same owl individuals, I used the map plotting function on artsobservasjoner.no to count the number of different sites ( $>2 \mathrm{~km}$ distance between plots; distance chosen to avoid overlap between home ranges of neighbouring owls, cf. Bekken et al. 1987) for each county. In 23 cases, multiple reports from the same site, but on different dates had already been merged into one report on artsobservasjoner.no at the time of data extraction. In the present study, the number of different sites was the important variable. Reduction in number of individual reports due to merging is of little importance because it does not change the number of sites. Although many Hawk Owls were reported over extended time periods at some sites, indicating that they may have established a wintering territory, other sites may have been used only for temporary stop-over, or observations may have been of individuals on migration. However, the likelihood that the same individuals had been observed at different sites was considered low, and not likely to affect the general patterns reported in this study. Although there were cases in which one report on artsobservasjoner.no concerned two or more individuals, the vast majority of reports concerned only one individual, and it was assumed that the number of sites corresponded to number of individuals. For Oslo and Akershus, bird reports are also submitted to www.nofoa.no, and to obtain the total number of sites with Hawk Owls in these two counties, I manually combined information on location of observations reported on the two websites (artsobservasjoner.no and nofoa.no). No reports in Oslo and Akershus concerned two individuals.

\section{Density extrapolation to other counties}

The number of bird reports varied between counties (see Table 1). To adjust for observation activity across counties, I used Hawk Owl reporting rate as an index

Figure 1. Location of survey routes in Oslo and Akershus counties, southeastern Norway, and observations of Northern Hawk Owls during September-October 2016. Hawk owl observations are marked with red dots, colour of survey routes indicate survey date (red: 25 September, light blue: 5 October, green: 21 October, yellow: 25 October, dark blue: 29 October, see Appendix 1 for further details about surveys). Note that boreal forest in Oslo and Akershus occurs in particular in eastern and northwestern parts of the counties. 
to correct the Hawk Owl density found in Oslo and Akershus. Hawk Owl reporting rate was taken as the proportion of all bird reports submitted to the website www.artsobservasjoner.no during September-October 2016 that concerned Hawk Owl. I made the assumption that in counties with a higher density of Hawk Owls, reports of hawk owls would constitute a greater proportion of all bird reports submitted, and conversely, in counties with a low Hawk Owl density, reports of Hawk Owls would constitute a smaller proportion of all bird reports. The number of Hawk Owls present in boreal forest in each county was thereafter calculated by using information on total area of forest in each county multiplied by the density obtained from Oslo and Akershus and corrected by the Hawk Owl reporting rate for each county relative to the Hawk Owl reporting rate in Oslo and Akershus (see Table 2).

\section{RESULTS}

\section{Hawk Owl density and numbers in Oslo and Akershus}

During $246 \mathrm{~km}$ survey a total of 16 Hawk Owls were detected (Figure 1), of which 13 were within $250 \mathrm{~m}$ from the survey roads. Thirteen individuals within 250 $\mathrm{m}$ on each side of $246 \mathrm{~km}$ survey length represents a minimum density of 0.106 individuals per $\mathrm{km}^{2}$. Oslo and Akershus counties have about 3,500 $\mathrm{km}^{2}$ forest, giving an estimate of 371 owls present during the study period. Using a more realistic estimate that took into account the proportion of suitable habitat (clear-cut) within a distance of $250 \mathrm{~m}$ from roads that were not checked (see Methods), the number of owls in boreal forests in Oslo and Akershus was 0.141 individuals per $\mathrm{km}^{2}$, corresponding to 494 individuals. Finally, using the maximum estimate $(52 \%$ detection rate within $250 \mathrm{~m}$ from survey roads) gives a density of 0.204 individuals per $\mathrm{km}^{2}$. This corresponds to 714 owls in boreal forests in Oslo and Akershus counties. Thus, the density of Hawk Owls in boreal forest in Oslo and Akershus was estimated to be $0.106-0.204$ individuals per $\mathrm{km}^{2}$, corresponding to 371-714 individuals. Ten owls were recorded on clear-cuts that were recently cut, four were on clear-cuts with young trees $2-5 \mathrm{~m}$ and one was in young forest. The remaining individual perched on a power line along which trees had been removed.

\section{Total number of Hawk Owl reports in southern Norway}

For all counties in Norway, there were 1,407 reports of Hawk Owls from 687 sites during September and October 2016 (Table 1), of which 1366 reports and 661 sites $(96 \%)$ were in southern Norway (Trøndelag and southwards; Table 1, Figure 2). On average, there were about six reports of Hawk Owls for every 1000 bird

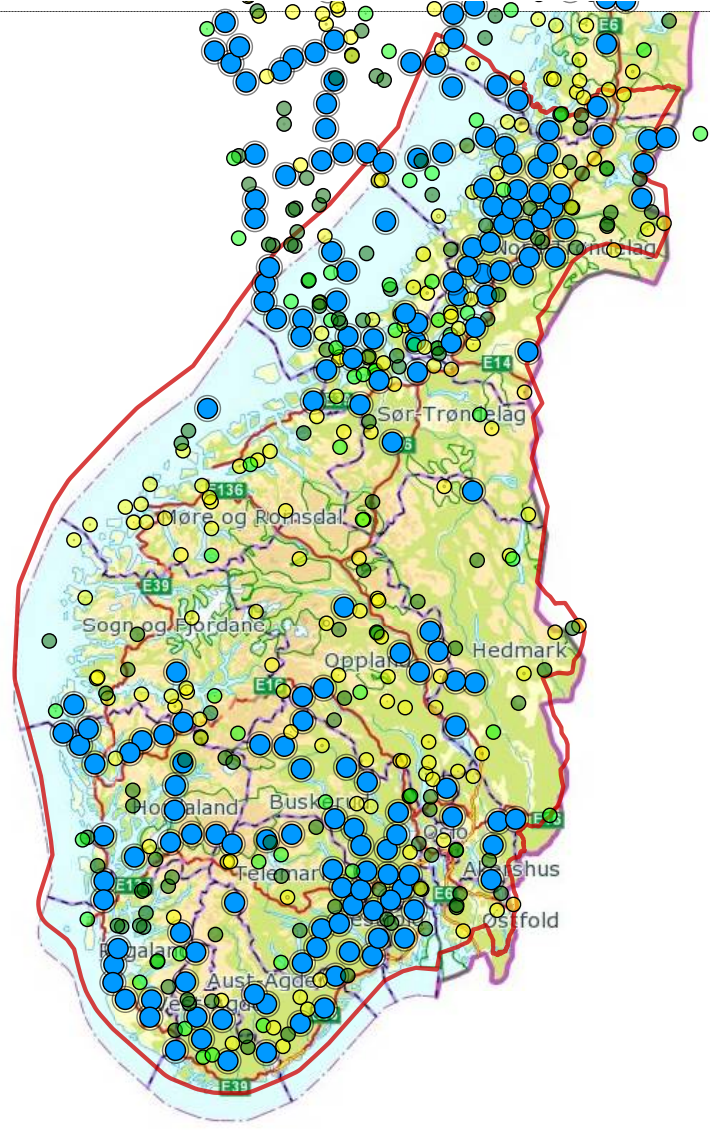

Figure 2. Locations of reports of Northern Hawk Owls in southern Norway during September-October 2016. Map generated from www.artsobservasjoner.no on 9 December 2016. Blue dots indicate clusters of observation sites. Other observation sites were treated equally in this study irrespective of colour (colour code not important for the present study).

reports, representing on average about three different sites discovered per 1000 bird reports (Table 1).

\section{Total number of Hawk Owls estimated from detection rates}

For Oslo and Akershus, 28 out of 38 discovered sites (74\%) were from boreal forests. Thus, the total number of sites with Hawk Owls was 1.36 times higher than for boreal forest only. This suggests that the total number of Hawk Owls (boreal forest and other habitats pooled) was $501-965$. The detection rate (38 out of 501-965 individuals) was therefore estimated at 3.9-7.6\%. A more conservative estimation of detection rate based only on the 371-714 individuals estimated for boreal forest suggested that $5.3-10.2 \%$ were detected (Table 2). Using a detection rate of $5-10 \%$, the 661 sites with Hawk Owls in southern Norway may have represented 6610-13220 individuals in total. However, detection 
Table 1. Number of reports of Northern Hawk Owls on the websites www.artsobservasjoner.no and www.nofoa.no in relation to total number of bird reports for each county in Norway during September and October 2016. Data were retrieved from websites on 30 November 2016.

\begin{tabular}{|c|c|c|c|c|c|}
\hline County & $\begin{array}{c}\text { Total } \\
\text { number of } \\
\text { bird reports }\end{array}$ & $\begin{array}{l}\text { Number of } \\
\text { Hawk Owl } \\
\text { reports }\end{array}$ & $\begin{array}{l}\text { Number of } \\
\text { Hawk Owl } \\
\text { reports per } \\
1000 \text { bird } \\
\text { reports }\end{array}$ & $\begin{array}{c}\text { Number of } \\
\text { Hawk Owl } \\
\text { sites }^{1}\end{array}$ & $\begin{array}{l}\text { Number of } \\
\text { Hawk Owl } \\
\text { sites per } \\
1000 \text { bird } \\
\text { reports }\end{array}$ \\
\hline Østfold & 15480 & 15 & 0.97 & 14 & 0.90 \\
\hline Oslo and Akershus & $14993\left(16942^{2}\right)$ & $37\left(62^{2}\right)$ & $2.47\left(3.66^{3}\right)$ & $21\left(38^{2}\right)$ & $1.40\left(2.24^{3}\right)$ \\
\hline Hedmark & 8597 & 41 & 4.77 & 29 & 3.37 \\
\hline Oppland & 6838 & 74 & 10.82 & 55 & 8.04 \\
\hline Buskerud & 8754 & 176 & 20.11 & 68 & 7.77 \\
\hline Vestfold & 25426 & 106 & 4.17 & 34 & 1.34 \\
\hline Telemark & 11948 & 207 & 17.33 & 102 & 8.54 \\
\hline Aust-Agder & 6665 & 43 & 6.45 & 35 & 5.25 \\
\hline Vest-Agder & 32466 & 205 & 6.31 & 47 & 1.45 \\
\hline Rogaland & 30549 & 121 & 3.96 & 59 & 1.93 \\
\hline Hordaland & 17937 & 170 & 9.48 & 88 & 4.91 \\
\hline Sogn og Fjordane & 4475 & 21 & 4.69 & 18 & 4.02 \\
\hline Møre og Romsdal & 5656 & 34 & 6.01 & 26 & 4.60 \\
\hline Sør-Trøndelag & 19715 & 41 & 2.08 & 30 & 1.52 \\
\hline Nord-Trøndelag & 8082 & 50 & 6.19 & 18 & 2.23 \\
\hline Nordland & 9441 & 25 & 2.65 & 14 & 1.48 \\
\hline Troms & 1651 & 12 & 7.27 & 8 & 4.85 \\
\hline Finnmark & 929 & 4 & 4.31 & 4 & 4.31 \\
\hline Total & $230251\left(232200^{2}\right)$ & $1382\left(1407^{2}\right)$ & $6.00\left(6.06^{3}\right)$ & $670\left(687^{2}\right)$ & $2.91\left(2.96^{3}\right)$ \\
\hline Southern Norway ${ }^{4}$ & $218230\left(220179^{2}\right)$ & $1341\left(1366^{2}\right)$ & $6.14\left(6.20^{3}\right)$ & $644\left(661^{2}\right)$ & $2.95\left(3.00^{3}\right)$ \\
\hline
\end{tabular}

${ }^{1}$ Locations $>2 \mathrm{~km}$ from each other

${ }^{2}$ Number of reports/sites from artsobservasjoner.no + from nofoa.no (this website included Hawk Owl records from the surveys conducted in the present study)

${ }^{3}$ Based on total number of bird reports from artsobservasjoner.no and nofoa.no

${ }^{4}$ Excluding Nordland, Troms and Finnmark counties

rates for southern Norway in general may have been lower than for Oslo and Akershus where 15 out of 38 sites were detected following special efforts in the field by the author of this paper. Using a detection rate of $2 \%$ (cf. overall detection rate estimated in Table 2, note that this was calculated via information on density and owl reporting rates), the total number of Hawk Owls in southern Norway would be 33050 individuals.

Total number of Hawk Owls estimated from density estimates

Based on the density estimates from surveys in Oslo and Akershus (see above, 0.106-0.204 owls $/ \mathrm{km}^{2}$ ) and the total forest area in southeastern Norway only (55600 $\mathrm{km}^{2}$, Table 2), the total number of Hawk Owls in forested parts of this region of Norway could be
5894-11342, with additional numbers in other habitats (such as agricultural areas), and other parts of southern Norway. The data from Oslo and Akershus (see above) suggested that $26 \%$ of owls were in other habitats than boreal forest. If this is representative for all of southeastern Norway, the numbers in agricultural areas in these counties would be 2061-3985 individuals. Table 1 indicates that the other counties in southern Norway (Vest-Agder, Rogaland, Hordaland, Sogn og Fjordane, Møre og Romsdal, Sør-Trøndelag and Nord-Trøndelag) had 286 out of the 661 sites (43\%) where Hawk Owls were observed in southern Norway. If the proportion of sites with Hawk Owls reflected proportion of all individuals, these parts of Norway may have had an additional 6001-11562 individuals. These calculations suggest that in total, 13956-26889 individuals may have been present in southern Norway.

However, using the density estimates from Oslo 
Table 2. Number of Northern Hawk Owls estimated in boreal forest in counties in southeastern Norway during September and October 2016. Estimated density was taken as the density estimates for Oslo and Akershus (0.106-0.204 individuals $\left./ \mathrm{km}^{2}\right)$, adjusted for number of hawk owl sites per 1000 bird reports (from Table 1) relative to the value for Oslo and Akershus (2.24).

\begin{tabular}{lccccc}
\hline County & $\begin{array}{c}\text { Estimated density } \\
\left.\text { (individuals } / \mathrm{km}^{2}\right)\end{array}$ & $\begin{array}{c}\text { Forest area } \\
\left(\mathrm{km}^{2}\right)^{1}\end{array}$ & $\begin{array}{c}\text { Number of } \\
\text { individuals }\end{array}$ & $\begin{array}{c}\text { Number of Hawk } \\
\text { Owl sites }{ }^{2}\end{array}$ & $\begin{array}{c}\text { Hawk Owl } \\
\text { detection rate }(\%)\end{array}$ \\
\hline Østfold & $0.043-0.082$ & 2700 & $116-221$ & 14 & $6.3-12.1$ \\
Oslo and Akershus & $0.106-0.204$ & 3500 & $371-714$ & 38 & $5.3-10.2^{3}$ \\
Hedmark & $0.159-0.307$ & 17200 & $2734-5280$ & 29 & $0.5-1.1$ \\
Oppland & $0.380-0.732$ & 10000 & $3800-7320$ & 55 & $0.8-1.4$ \\
Buskerud & $0.368-0.708$ & 7800 & $2870-5522$ & 68 & $1.2-2.4$ \\
Vestfold & $0.063-0.122$ & 1400 & $88-171$ & 34 & $1.9-38.6$ \\
Telemark & $0.404-0.778$ & 8100 & $3272-6302$ & 102 & $1.5-2.9$ \\
Aust-Agder & $0.248-0.478$ & 4900 & $1215-2342$ & 35 & $1.3-2.6$ \\
Total & & & & & 375 \\
\hline
\end{tabular}

${ }^{1}$ Data from http://forskning.no/skog-skogbruk/2013/01/hvilket-fylke-har-mest-skog

${ }^{2}$ Based on all Hawk Owl sites discovered (see Table 1), irrespective of habitat (note that this leads to an overestimation of detection rate)

${ }^{3}$ If sites discovered in this study were excluded (15 out of 16 owls detected had not been recorded by other observers before), $3.2-6.2 \%$ of the owls were detected

and Akershus may underestimate numbers because many counties had higher owl reporting rates than Oslo and Akershus (Table 1). Large counties such as Oppland, Buskerud and Telemark had owl reporting rates that were much higher than the national average, suggesting that these counties had particularly high Hawk Owl densities. Adjusting density according to the reporting rate of each county relative to the reporting rate in Oslo and Akershus (Table 2), indicated that the total number of Hawk Owls in forested parts of this region of Norway may have been 14466-27872. Using similar calculations as above, there would be 50839777 individuals in agricultural areas in southeastern Norway and 14747-28368 individuals in other parts of southern Norway, giving a total for southern Norway of 34296-65972 individuals.

\section{DISCUSSION}

\section{Density and numbers in Oslo and Akershus}

The surveys suggested a density of $0.106-0.204$ owls/ $\mathrm{km}^{2}$ in boreal forests of Oslo and Akershus. Assuming that most of the total forested area in the two counties could be suitable for Hawk Owls (because most of the forest is boreal forest), this represented a total of 371714 individuals (494 individuals as the most realistic estimate). This estimate was based on $246 \mathrm{~km}$ survey length over five days. Analyses indicated that density estimates stabilized after a few days of survey (see Appendix 2), and it seems unlikely that further survey effort would have changed estimates substantially.
The surveys were conducted along forestry roads. One could argue that there is more habitat suitable for Hawk Owls close to forestry roads due to more clearcutting along forestry roads, so that density estimates were inflated. However, most areas of boreal forest in Oslo and Akershus are affected by forestry, and most areas are close to forestry roads. Thus, the surveyed areas are representative for large parts of the forest in Oslo and Akershus. On the other hand, areas little affected by forestry are mostly located on higher hills where forest is less dense and interspersed with mires, and such areas may also be suitable for Hawk Owls (Sonerud 1994). One could also argue that Hawk Owls would concentrate along roads because of suitable hunting habitat along road verges or that small mammals killed by traffic could be an attractive source of food. However, except for part of the survey on one day (25 October), surveys were along narrow forestry roads adjoining forest directly without much road verge habitat, and roads had almost no traffic and no dead small mammals were observed on the roads. Thus, the forest along survey roads was considered to be representative and without relevant habitat bias.

The first survey day yielded no owls, but this survey was conducted in the most nutrient-poor area with large areas of pine forests that may have had low food availability. In general, the autumn of 2016 had increasing and relatively high densities of small mammals (Bank Vole Myodes glareolus, Wood Mouse Apodemus sylvaticus, and shrews Sorex spp.) in many areas in southeastern Norway (Geir A. Sonerud and Vidar Selås, personal communications), and probably extending to most parts of southern Norway. Spatial 
variation in small mammal densities could lead to uneven hawk owl densities, but reports on www. artsobservasjoner.no (Table 1) rather indicated that Hawk Owls were widespread and occurred in high densities across large areas, possibly with somewhat lower densities in southern coastal areas and in Trøndelag. In conclusion, it appears reasonable to estimate Hawk Owl numbers over large areas based on density in representative habitat.

\section{Total numbers in southern Norway based on detection} rates

Overall, the irruption appeared to take place in all counties in southern Norway (Figure 2). Hawk Owls were reported from a total of 661 sites in southern Norway, but it is likely that huge areas of in particular boreal forest were not visited by birdwatchers (Figure 2). One way to assess the total number of Hawk Owls present may be to make assumptions about how large proportion of the individuals were detected. This could be estimated for Oslo and Akershus via the density estimates, and this suggested that 5-10\% may have been detected. Using this detection rate, 6610-13220 individuals may have been present in southern Norway. This must, however, be considered an absolute minimum because detection rates most likely were lower in many areas with fewer birdwatchers than in Oslo and Akershus counties which is the most densely populated part of Norway, and with $17 \%$ of all members of the BirdLife Norway concentrated on $1.7 \%$ of the total area of Norway. In addition, 15 out of 38 Hawk Owls reported in Oslo and Akershus were detected during the surveys conducted in the present study. Excluding owls detected during the present surveys gave a detection rate of 3-6\%. Although it is possible that some birdwatchers in other counties concentrated on finding Hawk Owls, many counties (in particular Hedmark, Oppland, Buskerud, Telemark and Aust-Agder) have very large areas of boreal forests compared to the number of active birdwatchers. In e.g. Oppland county there is only one member of BirdLife for every $30 \mathrm{~km}^{2}$ forest, and most birdwatchers spend little time in boreal forest habitat (S. Dale, pers. obs. from Oslo and Akershus). If detection rates in general were only $2 \%$, the total number of Hawk Owls would be 33050 .

Total numbers in southern Norway based on density estimates

If the density found in Oslo and Akershus (0.106-0.204 owls $/ \mathrm{km}^{2}$ ) was representative for all boreal forest in southeastern Norway, the number of owls would be 5894-11342 plus most likely a few thousand in agricultural areas and in other parts of southern Norway. This estimate is fairly similar to that obtained by using detection rates (see above). However, in this case there is also reason to believe that the figures may represent understimation. There are no density estimates from other parts of southern Norway than Oslo and Akershus counties, but it is reasonable to believe that differences in density between counties could be reflected by owl reporting rates. High density of Hawk Owls can be assumed to lead to a higher proportion of Hawk Owl reports out of all bird reports submitted to www. artsobservasjoner.no. In particular, if multiple reports of the same owl individuals were excluded, the number of Hawk Owl sites found in relation to total number of bird reports may be a useful measure of relative density. Obviously, this measure is indirect and may be prone to biases (e.g. as suggested above that some birdwatchers may have focused on finding Hawk Owls), but from Table 1 it seems clear that Oslo and Akershus and neighbouring counties to the south (e.g. Østfold and Vestfold) had lower owl reporting rates than many other counties. Several large counties with large areas of boreal forest (Oppland, Buskerud and Telemark) had reporting rates that were more than three times higher than that of Oslo and Akershus (using the site reporting rate which corrected for multiple reporting of same individuals). The average reporting rate for all of southern Norway was 34\% higher than that of Oslo and Akershus. Using reporting rate directly to adjust county-wise densities (Table 2) suggested there were 14466-27872 individuals in boreal forests in southeastern Norway, and in addition there were probably several thousand in agricultural areas and in other parts of southern Norway. Using an average density 34\% higher than Oslo and Akershus gives a corresponding number of 7898-15198 individuals in boreal forests in southeastern Norway.

Although the estimates of the total number of individuals in southern Norway presented here differed substantially, as expected when total numbers were based on upscaling in several steps from observed numbers, it is still remarkable that even the most conservative estimates indicated a total number of roughly 10000 individuals. Given that there were several reasons to assume that some of the numbers represented clear underestimation, it seems probable that numbers may have been as high as 20000 individuals. Other estimates were even higher, in particular those that extrapolated densities for other counties than Oslo and Akershus through owl reporting rates, but this way of estimation may be the least reliable method among those used here. Thus, I suggest that the total number of Hawk Owls present in southern Norway during the 2016 irruption may have been in the range 10000 20000 individuals. I am unaware of any calculations of the total number of Hawk Owls involved in the 1983- 
84 irruption in Norway, but Jacobsen (1984) reported 350 observations of Hawk Owls during 1983-84 in Hordaland county, of which 276 were from SeptemberNovember 1983 which compares well with the 224 Hawk Owl reports during September-November 2016. Thus, the 2016 irruption seems to have been of similar magnitude as the 1983-84 irruption. In Värmland in Sweden, numbers may have been 2000-4000 during the 1983-84 irruption (Svensson et al. 1999). Värmland has an area of ca. $18000 \mathrm{~km}^{2}$ of which most is forested, and the resulting density of $0.1-0.2$ owls per $\mathrm{km}^{2}$ is very similar to the findings of the present study (0.106$0.204 \mathrm{owls} / \mathrm{km}^{2}$ ). Jacobsen (1984) claimed that the 1950-51 irruption involved 4000 individuals reaching southern Scandinavia, however, this appears to be a misunderstanding of Hagen (1956) who calculated a density of 4000 individuals within $40000 \mathrm{~km}^{2}$ breeding habitat in the year before the irruption. Note also that the resulting pre-irruption density of 0.1 owls per $\mathrm{km}^{2}$ is similar to the values obtained in the present study.

\section{Origin of the 2016 irruption}

Hawk Owls breed irregularly and in low numbers in southern Norway, and during the breeding season of 2016 there were only 14 reports of Hawk Owls from May to mid August in southern Norway on www. artsobservasjoner.no (27 during April-July of which 14 were during the first half of April), and only one of these was of confirmed breeding. In northern Norway (Nordland, Troms and Finnmark counties) there were 139 reports during April-July, including about 15 confirmed breeding sites. However, in northern Norway the number of breeding Hawk Owls was far greater during 2015. According to www.artsobservasjoner. no, there were 213 reports during April-July 2015. However, this does not fully reflect the fact that 2015 was one of the best breeding seasons for Hawk Owls in northern Norway on record, and that some of these birds remained in the area until spring 2016, but relatively few bred because of a crash in the small mammal population (Karl-Birger Strann, pers. comm.). Note also that very few Hawk Owls reached southern Norway during the autumn of 2015 (36 reports on www.artsobservasjoner.no during September-October 2015 compared to 1341 reports during SeptemberOctober 2016).

A similar situation was evident in northern Sweden (Norrbotten, Västerbotten, Jämtland and Västernorrland), with 186 reports on the Swedish Species Observations System (www.artportalen.se) during April-July 2016, but 615 reports during AprilJuly 2015. Also, the number of Hawk Owl reports from southern Sweden was low during the breeding season of both years ( 25 in 2015, 23 in 2016). The large owl numbers from the 2015 breeding season did not reach southern Sweden in the autumn of 2015 (15 reports on www.artportalen.se during September-October 2015 compared to 550 reports during September-October 2016).

In Finland, the 2015 breeding season was good for Hawk Owls, but data on breeding success for 2016 have not yet been analysed (Markus Piha, pers. comm.). However, the number of reports for the whole of Finland on the Finnish Bird Reporting System (www.tiira.fi) during the breeding seasons (April-July) of 2015 and 2016 was quite similar (425 versus 419). Most of these records were from northern Finland. The numbers reaching southern Finland (Södra, Västra and Östra Finlands län) were higher during SeptemberOctober 2016 (more than 110 reports) than in the same period in 2015 (41 reports). Finland appears to differ from Norway and Sweden in that there was a smaller difference in numbers between the breeding seasons of 2015 and 2016, and that the irruption in southern Finland in the autumn of 2016 was much less marked; the number reported during 2016 was about three times higher than in 2015 compared to 37 times higher for both southern Norway and southern Sweden.

Overall, the irruption in southern Norway could be interpreted as a result of the large number of breeding Hawk Owls in northern Fennoscandia during 2015 that subsequently moved south after the rodent crash during late winter and early spring 2016. This explanation apparently leaves a gap in reports during the breeding season of 2016. The number of birds reported in northern Norway and Sweden during April-July 2016 was much lower than during April-July 2015, and hawk owls did not start to appear in southern Fennoscandia before mid August. However, it appears possible that many of the Hawk Owls were present in northern Finland during this period before moving south (see above).

Previous irruptions of Hawk Owls have been claimed to originate from the east (Holgersen 1951, Edberg 1955) although Hagen (1956) argued that the 1950-51 irruption came from within Fennoscandia. Exchange of individuals between Norway and Russia has been documented by ringing (Bakken et al. 2006). Irruptions in Finland have also been assumed to come from the east (Mikkola 1983). The 2016 irruption has already been claimed to come from the east (Anonymous 2016, Larsen 2016, Natursidan.se 2016). Hawk Owls on migration have been observed arriving to east-central Sweden from the Baltic Sea (Rastén 2016), although these birds appeared to arrive from the north. In July 2016, there were only 10 reports of Hawk Owls in Sweden on www.artportalen.se, all of them in the northern half of the country. In August, there were 41 reports, most of them in northern Sweden and with a concentration along the Fennoscandian mountain chain, not along the eastern coast. This might suggest an initial movement corridor from the north. However, in September, there were 226 reports with a 
sudden large increase in southern Sweden, in particular along the eastern coast, which could be compatible with an eastern origin. The location of the records of Hawk Owls in September 2016 in southern Sweden might indicate westward migration across the Baltic sea. However, Cramp (1985) suggested that the Baltic Sea forms a fairly effective barrier with Hawk Owls crossing only infrequently. A concentration along the Swedish east coast could also occur if birds moving from the northwest avoid migrating out over the sea, but follow the coastline southwards (cf. Rastén 2016).

Furthermore, there have been no reports of large numbers of breeding Hawk Owls during the breeding season of 2016 in Russia, or large-scale movements of Hawk Owls in Russia during the autumn of 2016 (Nikita Chernetsov, pers. comm.), although the size of Russia makes absence of evidence difficult to interpret. Similarly, in Estonia there were only seven reports of Hawk Owls during the autumn of 2016 compared to four reports during the autumn of 2015 (Jaanus Elts, pers. comm.), far less than during the 2013 irruption when there were 32 reports (Estonian Nature Tours 2013). In southern Finland, there were more reports of Hawk Owls during September-October 2016 than in the same period in 2015 (see above), but the difference between the years was far smaller than in Norway and Sweden. Thus, there is no evidence that the irruption originated from areas east of Finland and the Baltic Sea.

If the Hawk Owls in southern Norway originated from northern Fennoscandia, there must have been huge numbers there during the breeding season of 2015. In addition to the estimated 10000-20000 birds in southern Norway, large numbers were probably also present in southern Sweden during the autumn of 2016. There were 627 reports on www.artportalen. se during September-October 2016, and most of these were in the southern half of Sweden. In peak years, the Norwegian breeding population size, concentrated in northern Norway, may be 1000-10000 pairs (Sonerud 1994, Shimmings \& Øien 2015). In Sweden, the number of breeding pairs may be around 2300 (112513510; Ottoson et al. 2012). In Finland, population size is estimated at 1000-6000 pairs (Väisänen et al. 2011). Saurola (1985) suggested that there may be 2-10 pairs per $100 \mathrm{~km}^{2}$ in good years, which for northern Fennoscandia would translate to approximately 8000 40000 pairs. Ottosson et al. (2012) report even higher breeding densities (10-50 pairs per $100 \mathrm{~km}^{2}$ ). Assuming 8000-40000 breeding pairs in 2015 and for example five surviving offspring per pair [Mikkola (1983) reported an average clutch size of 6.3 across years, and an average of 10.2 in good vole years], the number of individuals in northern Fennoscandia during the autumn of 2015 may have been 56000-280000. Thus, breeding population sizes suggest it is possible that the large number of Hawk Owls in southern Fennoscandia in the autumn of 2016 could have involved birds moving from northern Fennoscandia after the peak breeding season of 2015. The autumn of 2016 witnessed a large influx to Fennoscandia of many eastern bird species assumed to come from Russia during the same time period as Hawk Owls appeared (e.g. Anonymous 2016, Ullman 2016). However, this does not appear to explain the influx of Hawk Owls because there were no reports of large owl numbers east of Finland and the Baltic Sea during the period preceding the irruption. Rather, the hawk owl irruption to southern Norway and Sweden in 2016 most likely came from northern Fennoscandia. This conclusion matches that of Hagen (1956) who argued that the 1950-51 irruption came from within Fennoscandia and not from Russia.

Acknowledgements. I thank Paul Shimmings, Roar Solheim and Geir A. Sonerud for comments on the manuscript.

\section{REFERENCES}

Anonymous. 2016. Rysk invasion. Vår Fågelvärld 2016 (5): 8.

Bakken, V., Runde, O. \& Tjørve, E. 2006. Norsk ringmerkingsatlas. Vol. 2. Stavanger Museum, Stavanger.

Bekken, B.T., Nybo, J.O. \& Sonerud, G.A. 1987. Home range size of Hawk Owls: dependence on calculation method, number of tracking days, and number of plotted perchings. USDA Forestry Service General Technical Report RM-142: 145-148.

Cheveau, M., Drapeau, P., Imbeau, L. \& Bergeron, Y. 2004. Owl winter irruptions as an indicator of small mammal population cycles in the boreal forest of eastern North America. Oikos 107: 190-198.

Cramp, S. (ed.) 1985. The Birds of the Western Palearctic, Vol. IV. Oxford University Press, Oxford.

Douhan, B. 2014. Hökugglan i Uppland. Fåglar i Uppland 2014 (1): 36-48.

Edberg, R. 1955. Invasionen av hökuggla (Surnia ulula) i Skandinavien 1950-51. Vår Fågelvärld 14: 10-21.

Estonian Nature Tours. 2013. Incredible Hawk Owl invasion in Estonia! http://estoniannature.blogspot.no/2013/11/ incredible-hawk-owl-invasion-in-estonia.html. Retrieved on 31 October 2016.

Hagen, Y. 1956. The irruption of Hawk-owls (Surnia ulula (L.)) in Fennoscandia 1950-51. Sterna 1 (24): 3-22.

Holgersen, H. 1951. Bird notes and news 1950. Sterna 1 (1): $1-10$.

Jacobsen, O.W. 1984. Invasjonsforløp av haukugler Surnia ulula i Hordaland høsten og vinteren 1983/84. Vår Fuglefauna 7: 135-139.

Larsen, J.O. 2016. Denne ugla har invadert Norge i høst. https://www.nrk.no/nordland/denne-ugla-har-invadertnorge-1.11291377. Retrieved on 31 October 2016.

Larsson, J.Y. 2013. Hvilket fylke har mest skog? http:// forskning.no/skog-skogbruk/2013/01/hvilket-fylke- 
har-mest-skog. Retrieved on 30 November 2016.

Mikkola, H. 1983. Owls of Europe. T \& AD Poyser, Calton, UK.

Natursidan.se. 2016. Invasion av hökugglor i landet just nu. http://www.natursidan.se/nyheter/invasion-avhokugglor-i-landet-just-nu/. Retrieved on 2 November 2016.

Newton, I. 2006. Advances in the study of irruptive migration. Ardea 94: 433-460.

Nybo, J.O. \& Sonerud, G.A. 1990. Seasonal changes in diet of Hawk Owls Surnia ulula: importance of snow cover. Ornis Fennica 67: 45-51.

Ottosson, U., Ottval, R., Elmberg, J., Green, M., Gustafsson, R., Haas, F., Holmqvist, N., Lindström, Å., Nilsson, L., Svensson, M., Svensson, S. \& Tjernberg, M. 2012. Fåglarna i Sverige - antal och förekomst. Sveriges Ornitologiska Förening, Halmstad.

Rastén, A. 2016. Hökuggleinvasion. http://www.biotopia.nu/ hokuggleinvasion/. Retrieved on 2 November 2016.

Saurola, P. 1985. Finnish birds of prey: status and population changes. Ornis Fennica 62: 64-72.

Shimmings, P. \& Øien, I.J. 2015. Bestandsestimater for norske hekkefugler. Norsk Ornitologisk Forening, rapport 2-2015.

Sonerud, G.A. 1986. Effect of snow cover on seasonal changes in diet, habitat, and regional distribution of raptors that prey on small mammals in boreal zones of Fennoscandia. Holarctic Ecology 9: 33-47.

Sonerud, G.A. 1992. Search tactics of a pause-travel predator: adaptive adjustments of perching time and move distances by Hawk Owls (Surnia ulula). Behavioral Ecology and Sociobiology 30: 207-217.

Sonerud, G.A. 1994. Haukugle Surnia ulula. In: Gjershaug,
J.O., Thingstad, P.G., Eldøy, S. \& Byrkjeland, S. (eds.): Norsk fugleatlas. Norsk Ornitologisk Forening, Klæbu. Sonerud, G.A. 1997. Hawk Owls in Fennoscandia: population fluctuations, effects of modern forestry, and recommendations on improving foraging habitats. Jounal of Raptor Research 31: 167-174.

Sonerud, G.A., Solheim, R. \& Prestrud, K. 1988. Dispersal of Tengmalm's Owl Aegolius funereus in relation to prey availability and nesting success. Ornis Scandinavica 19: 175-181.

Sundell, J., Huitu, O., Henttonen, H., Kaikusalo, A., Korpimäki, E., Pietiäinen, H., Saurola, P. \& Hanski, I. 2004. Large-scale spatial dynamics of vole populations in Finland revealed by the breeding success of voleeating avian predators. Journal of Animal Ecology 73: 167-178.

Sunding, P. \& Hjermann, D.Ø. 2009. Den nemorale løvskogssonen. https://snl.no/Den_nemorale_ løvskogssonen. Retrieved on 30 November 2016.

Svensson, S., Svensson, M. \& Tjernberg, M. 1999. Svensk Fågelatlas. Sveriges Ornitologiska Förening, Stockholm.

Väisänen, R.A., Hario, M. \& Saurola, P. 2011. Population estimates of Finnish birds. In: Valkama, J., Vepsäläinen, V. \& Lehikoinen, A. 2011. The Third Finnish Breeding Bird Atlas. Finnish Museum of Natural History and Ministry of Environment. http://atlas3.lintuatlas.fi/ english. Retrieved on 21 December 2016.

Ullman, M. 2016. Invasion från öster. Vår Fågelvärld 2016 (6): 46-53.

Received 9 January 2017. Accepted 8 March 2017 
Appendix 1. Northern Hawk Owl surveys conducted during the autumn of 2016 in Oslo and Akershus counties, southeastern Norway.

\begin{tabular}{|c|c|c|c|c|c|c|c|}
\hline \multirow[b]{2}{*}{ Survey site } & \multirow[b]{2}{*}{ Municipality } & \multirow[b]{2}{*}{ Date } & \multicolumn{3}{|c|}{ Survey length (km) } & \multicolumn{2}{|c|}{ No. of owls } \\
\hline & & & Car & Bicycle & Total & Observed & Per km \\
\hline Sagstusjøen-Viksjøen & Nes, Aurskog-Høland & 25 September & 0 & 47.5 & 47.5 & 0 & 0 \\
\hline Kampåa-Grønnsjøen & Nes, Eidsvoll & 5 October & 35.1 & 4.6 & 39.7 & 4 & 0.101 \\
\hline Sjonken-Øyangen & Nannestad, Hurdal & 21 October & 33.8 & 8.1 & 41.9 & 5 & 0.119 \\
\hline Mangen-Mjermen & Aurskog-Høland & 25 October & 73.7 & 2.0 & 75.7 & 4 & 0.053 \\
\hline Nordmarka & Oslo & 29 October & 0 & 40.9 & 40.9 & 3 & 0.073 \\
\hline Total & & & 142.6 & 103.1 & 245.7 & 16 & 0.065 \\
\hline
\end{tabular}

Appendix 2. Reports of injured or killed Northern Hawk Owls along roads, other accidents, and weakened birds in southern Norway during August-November 2016.

\begin{tabular}{|c|c|c|}
\hline Date & County & Reference \\
\hline \multicolumn{3}{|c|}{ Injured or killed along roads } \\
\hline 17 August & Rogaland & http://www.artsobservasjoner.no/Sighting/15223250 \\
\hline 11 September & Buskerud & http://www.artsobservasjoner.no/Sighting/15384680 \\
\hline 29 September & Sør-Trøndelag & $\begin{array}{c}\text { http://www.opdalingen.no/nyheter/2016/09/30/Reddet-haukugle- } \\
\text { på-riksvei-70-13572264.ece }\end{array}$ \\
\hline 2 October & Telemark & http://www.artsobservasjoner.no/Sighting/15537393 \\
\hline 12 October & Buskerud & http://www.artsobservasjoner.no/Sighting/15603335 \\
\hline 13 October & Nord-Trøndelag & $\begin{array}{l}\text { http://www.bladet.no/nyheter/2016/10/16/Skadet-haukugle- } \\
\text { i-pensjon-13652661.ece }\end{array}$ \\
\hline 15 October & Buskerud & http://www.artsobservasjoner.no/Sighting/15616953 \\
\hline \multicolumn{3}{|l|}{ Other accidents } \\
\hline 4 September & Oslo & http://www.artsobservasjoner.no/Sighting/15368419 \\
\hline 6 September & Aust-Agder & http://www.irisor.no/2016/09/06/haukugel-satt-fast-perleporten/ \\
\hline 1 October & Vestfold & http://www.artsobservasjoner.no/Sighting/15534111 \\
\hline 3 October & Rogaland & http://www.artsobservasjoner.no/Sighting/15542047 \\
\hline \multicolumn{3}{|l|}{ Weakened birds } \\
\hline 3 October & Hordaland & http://www.artsobservasjoner.no/Sighting/15587696 \\
\hline 6 November & Oslo & http://www.artsobservasjoner.no/Sighting/15819006 \\
\hline
\end{tabular}




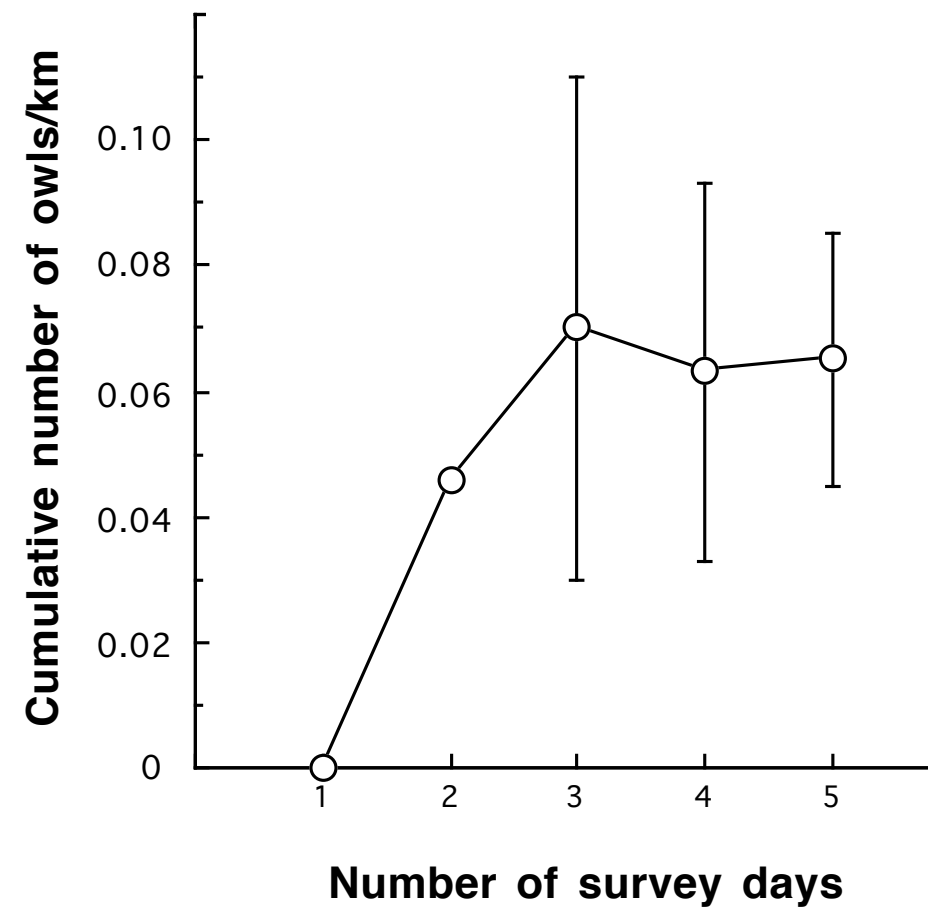

Appendix 3. Cumulative recording rate (individuals $/ \mathrm{km}$ road surveyed) of Northern Hawk Owls as a function of number of survey days during the autumn of 2016 in Oslo and Akershus counties, southeastern Norway. Bars show SE of mean daily detection rates from third survey day.

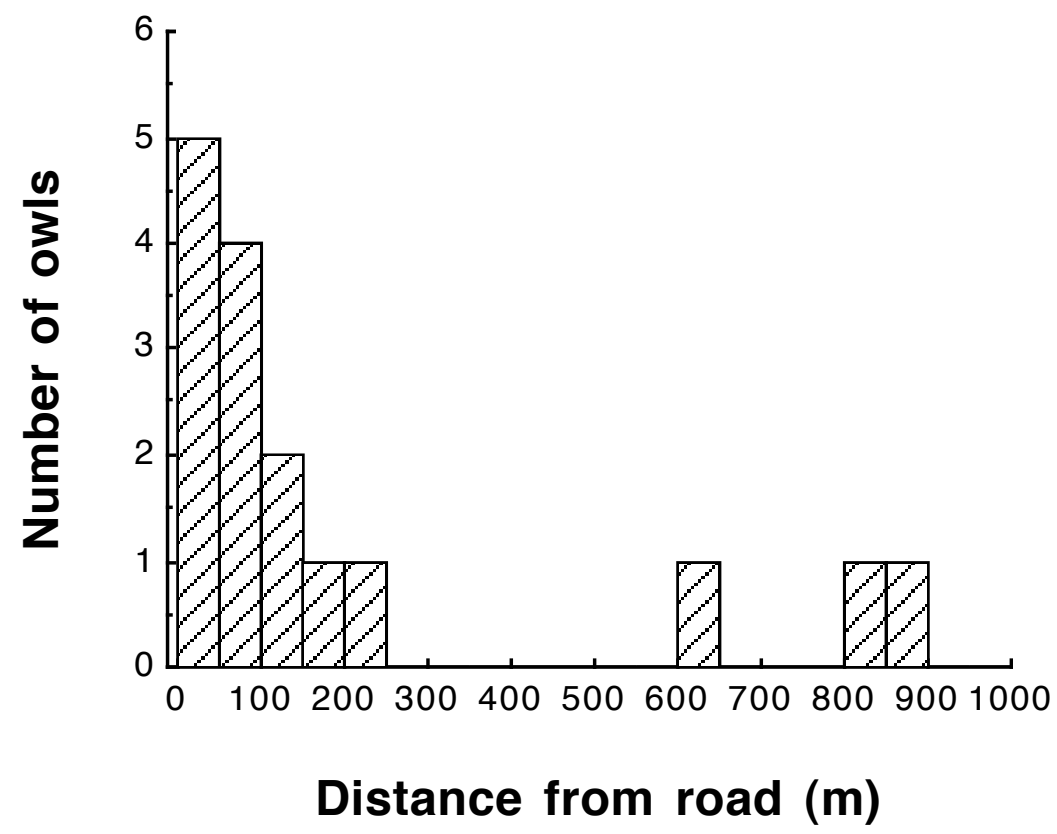

Appendix 4. Perpendicular distance from road of Northern Hawk Owls detected during surveys during the autumn of 2016 in Oslo and Akershus counties, southeastern Norway. Within $250 \mathrm{~m}$ from the roads, number of owls detected declined with distance from road for each $50 \mathrm{~m}$ interval $\left(\mathrm{r}_{\mathrm{S}}=-0.97, \mathrm{n}=5, \mathrm{P}=0.051\right)$. 


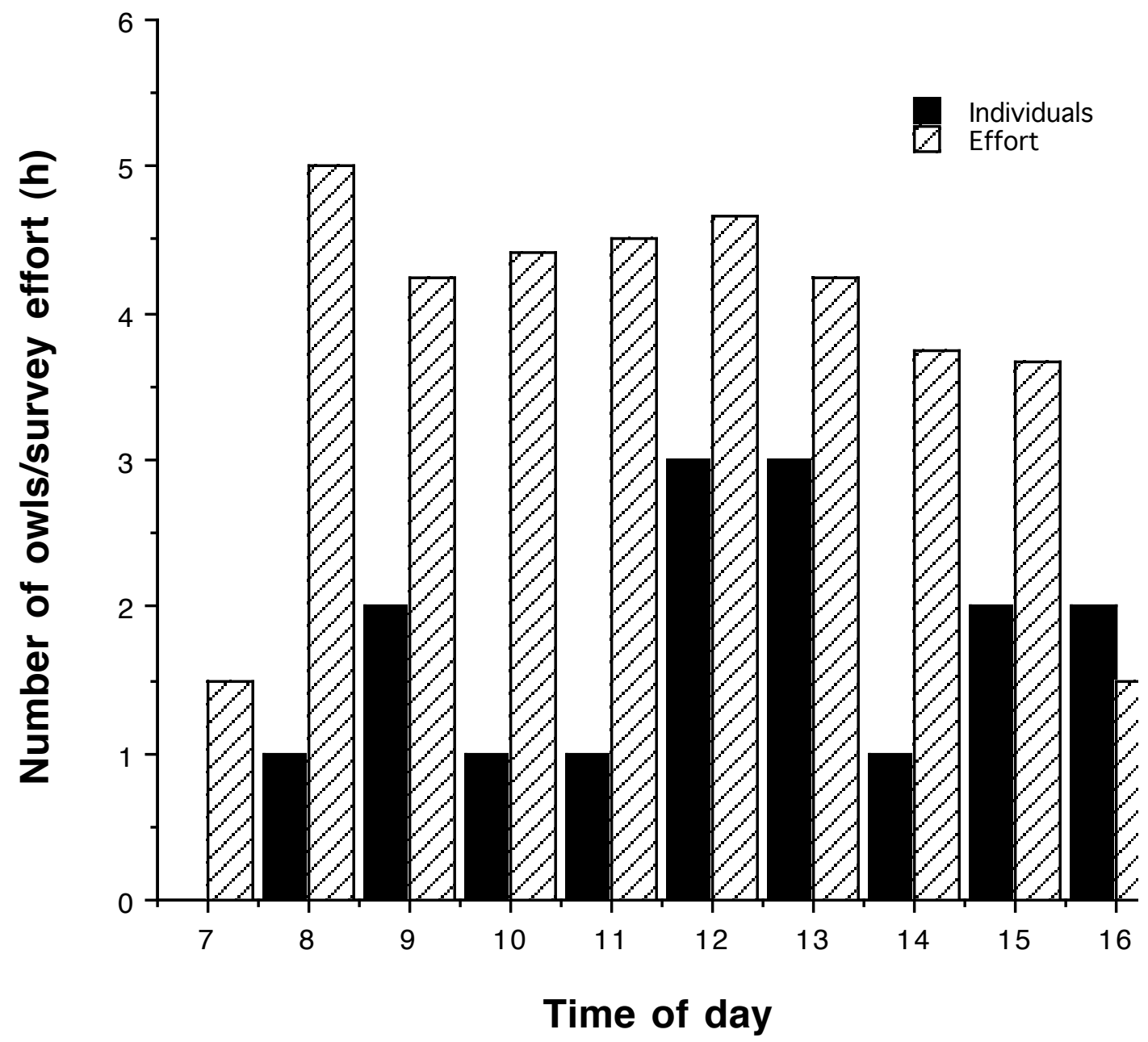

Appendix 5. Number of Northern Hawk Owls detected and survey effort (hours) in relation to time of day during the autumn of 2016 in Oslo and Akershus counties, southeastern Norway. Hourly effort was below 5 hours for several hourly intervals despite five survey days due to car transport from one subarea to another (on some survey days several access points to different forestry roads were used). Sunrise was between 0707 hours and 0830 hours during the study period. 